\title{
Portefeuljebestuur, die kapitaalmarkprysmodel en verwante tegnieke
}

\author{
J. Van Zyl Smit \\ Departement Rekeningkunde, Universiteit van Stellenbosch, Stellenbosch 7600, Republiek van Suid-Afrika
}

Ontvang 21 Augustus 1990; aanvaar 24 Oktober 1990

\begin{abstract}
The importance of risk management in business has long been recognised. The importance, assumptions and limitations of the Capital Asset Pricing Model is generally accepted and an elaborate introduction is therefore not necessary. The stability of returns on investments is both a measure of risk and a cardinal determinant of the Capital Asset Pricing Model which deals with risk and reasonable renum. The Capital Asset Pricing Model as prospective valuation instrument is subject to serious limitations. Certain determinants of the model can however be shown to be of great theoretical and practical importance in techniques of prospective value. To develop a theoretically sound practical retum measure with predictive value to be appliod in conjunction with the Capital Asset Pricing Model would constitute a meaningful contribution to investment management. This article is based on a study carried out on a small sample of companies quoted on the Johannesburg Stock Exchange during the period 1982 to 1990 with a view to illustrate the application in portfolio management of the Capital Asset Pricing Model and its short-term predictive value in respect of share price movements. In addition a number of techniques complementary to the Capital Asset Pricing Model were developed and illustrated.
\end{abstract}

Die belangrikheid van risikobestuur in besigheid geniet lank reeds erkenning en die toepassingsveld, aannames en beperkinge van die markpryswaarderingsmodel is so algemeen bekend dat die uitvoerige bekendstelling daarvan onnodig is. Die stabiliteit van opbrengste op beleggings is beide 'n maatstaf van risiko en 'n hoofveranderlike van die markpryswaarderingsmodel waardeur risiko's en redelike opbrengste met mekaar in verband gebring word. Die markpryswaarderingsmodel is as vooruitskattingstegniek aan beperkinge onderhewig. Sekere veranderlikes van die markpryswaarderingsmodel is egter van teoretiese en praktiese belang by beplanning en vooruitskattings. Indien 'n teoreties-gefundeerde, prakties-werkbare opbrengsmaatstaf met voorspellingswaarde ontwerp kan word om saam met die markpryswaarderingsmodel aangewend te word, kan dit 'n betekenisvolle bydrae tot beleggingsbestuur lewer. Hierdie artikel is gebaseer op 'n studie wat uitgevoer is op 'n klein steekproef van maatskappye wat op die Johannesburgse Effektebeurs genoteer was vir die periode 1982 tot 1990. Die doel van die studie is om die toepassing in portefeuljebestuur van die markpryswaarderingsmodel en sy vermoè om korttermynaandeleprysbewegings aan te dui, te illustreer. 'n Aantal tegnieke, komplementêr tot die markpryswaarderingsmodel, is ontwikkal en word geillustreer.

\section{Doel}

Die doel van hierdie artikel is om die kapitaalmarkprysmodel (KMPM) en verwante tegnieke te illustreer en hul plek in portefeuljebestuur aan te dui.

As vertrekpunt word aanbeveel dat die volgende algemeen bekende tegnieke aangewend word by die voorlopige identifikasie van aandele wat moontlik opgeneem kan word in 'n portefeulje van 'n beleggermaatskappy:

- Konvensionele tegnieke

- Kartering

- Finansiële ontleding

- Stremmingsvoorspellingstegnieke

Hiernaas word aanbeveel dat die KMPM en verwante tegnieke, wat later toegelig sal word, aangewend word by die samestelling van 'n effektiewe portefeulje.

\section{Metodiek}

Standaardtegnieke ${ }^{d}$ word toegepas by die daarstel van die illustratiewe berekeninge van opbrengste en ander statistiese data met betrekking tot die periode van agt jaar van 1982 tot 1990.

Die data is ten opsigte van gewone aandele van maatskappye genoteer op die Johannesburgse Effektebeurs. Die maatskappye is ewekansig gekies uit 'n kortlys van aandele uit 'n tiental industriez. Ten einde vergelykbaarheid te bevorder sluit die lys slegs maatskappye met Junie-jaareindes in wat nie wesenlik gerekonstrueer is gedurende die agtjaar-periode nie.

Die opbrengste van die aandele is bereken vanaf die kwartaallikse toename of afname in die markprys van die aandeel plus diwidende betaal gedurende die kwartaal. Standaardafwykings, gemiddeldes en dies meer is bereken vir die opbrengste.

Die steekproef van 22 maatskappye is te klein om in alle gevalle tot klinkklare statistiese gevolgtrekkings te kom, maar dien goed as illustratiewe voorbeelde.

Die grondliggende formules wat gebruik is by die berekening van markbetas en ekwilibrium-verwagte opbrengste volgens die kapitaalmarkprysmodel is die volgende:

\section{Markbeta}

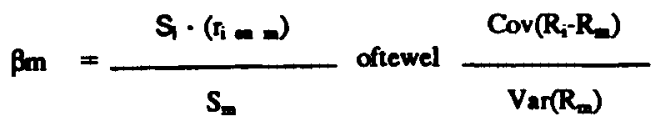

\section{Ekwilibrium opbrengs}

$$
E\left(R_{i}\right)=R_{f}+\beta^{m} \cdot E\left(\bar{R}_{m}-R_{f}\right)
$$

Beskrywing van terme
$\begin{aligned} \mathbf{E}(\overline{\mathrm{R}}) \quad & \text { Verwagte ekwilibrium opbrengs van die aandeel } \\ & \text { vir een periode }\end{aligned}$
$\begin{aligned} \mathbf{R}_{\boldsymbol{f}} \quad & \text { Opbrengs op ' } \mathrm{n} \text { risikovrye belegging vir } \\ & \text { cen periode }\end{aligned}$
$\begin{array}{ll}\boldsymbol{\beta} \mathrm{m} \quad & \text { Markbeta (regressielynkoeffisiënt) } \\ \mathbf{E} & =\text { Gelykluidende opbrengs vir cen periode }\end{array}$


$\dot{\mathrm{R}}_{\mathrm{m}} \quad=$ Opbrengs op 'n markindeks van aandele vir een periode

$S_{i} \quad=$ Standaardafwyking van die opbrengs van 'n aandeel vir een periode

$S_{m} \quad=$ Standaardafwyking $v$ an die opbrengs van die markindeks van aandele vir een periode

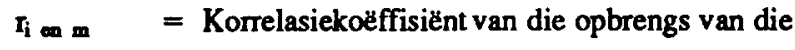
aandeel $i$ en die markindeks $m$

Die volgende beperkinge wat algemeen aanvaar word, onderliggend aan hierdie tegnieke, moet ter aanvang reeds vermeld word:

- Die aanname van reglynige verwantskappe by opbrengste is nuttig en redelik binne perke maar nie absoluut nie.

- Die doeltreffende markhipotese waarvolgens alle belangrike data onmiddellik bekend word en volledig in die markprys van aandele verreken word, is oordrewe.

- Die voorspellingswaarde van markpryse en opbrengskoerse van periode tot periode is beperk.

\section{'n Beleggingseleksienorm aanvullend tot} kapitaalmarkprysmodel en tradisionele tegnleke

Een van die mees algemene riglyne met betrekking tot redelike opbrengskoerse en risiko's wat hedendaags gebruik word, is die deursnee markopbrengskoers.

'n Beredeneerde norm, aanvullend hiertoe, is 'n opbrengs om die belegger te vergoed vir die effek van inflasie, die uitstel van besteding en die risiko van kapitaalverliese. stel:

Die volgende koerse word vir illustrasiedoeleindes ge-

Inflasie

Uitstelvergoeding

Risikovergoeding

Verwagte opbrengs op lae risikobelegging

Vir doeleindes van hierdie artikel is 'n hipotetiese belegging wat met inflasie groei oor agt jaar plus 'n $1 / 2 \%$ per kwartaal geneem en vergelyk met werklike aandele en die goud- en industrielle indekse. Die KMPM is op laasgenoemde gebaseer.

Uit wat volg sal blyk dat bogenoemde norm uitstekend vergelyk met die sogenaamde deursnee markopbrengste en in bykans perfekte ekwilibrium daarmee verkeer. Dit verskaf minstens 'n mate van praktiese onderskrywing van hierdie norm.

Dié norm is waarskynlik van groter intydse en voorspellingswaarde as die KMPM wat hoofsaaklik 'n ex post-verklaring is. Dit kan ook 'n aanduiding verskaf van aandele wat op 'n ex post-basis uit ekwilibrium is en moontlik oor die kort termyn na ekwilibriumstand kan terugkeer.

Dié norm kan van nut wees vir beide die corspronklike seleksie van aandele asook vir die keuse van aandele uit dié aandele wat nie in ekwilibrium verkeer nie.

Belastingaansuiwerings moet, waar toepaslik, gemaak word ten einde 'n na-belaste opbrengs van die aangeduide omvang te lewer.
Tabel 1 kan van nut wees by die beoordeling van die redelikheid van beleggingsopbrengste met inagneming van die graad van risiko, stabiliteit van opbrengste en opbrengskoerse.

Die opbrengs van die maatstaf en die standaardafwykings daarvan is in ekwilibrium met dié van die mark volgens die industrièle indeks. Daar word aanbeveel dat die twee saam aangewend word om die beleggingskwaliteit van 'n aandeel en portefeulje te beoordeel.

\section{Berekeninge en Inligting}

Die inligting in Tabel 2 is bereken en saamgestel uit kwartaallikse data uit die 'Financial Mail' asook die 'Stock Exchange Handbook' oor 'n periode van dertig kwartale vanaf 1982 tot 1990.

\section{Die ekwilibriumgaping as beleggingswerktuig}

Volgens die KMPM kan die verlangde opbrengs van 'n aandeel bereken word aan die hand van die markbeta van die aandeel, die markopbrengs en die vlak van 'n risikovrye opbrengs.

Indien die verlangde opbrengs laer is as wat tans gelewer word deur die aandeel, sal die aandeel se prys neig om te styg tot die ekwilibriumopbrengs bereik word.

Hierdeur bied die tegniek 'n hulpmiddel by die keuse van aandele met 'n potensiaal om te verbeter tot die ekwilibriumvlak oor die kort tot medium termyn.

Ter illustrasie is die steekproef van aandele verwerk en die resultate verkry in Tabel 3 weergegee.

Die verwantskap tussen die Verlangde opbrengs en die Behaalde opbrengs blyk uit die volgende korrelasies:

$r-0,48$

$r^{2}=0,24$

Uit bogenoemde blyk dit dat daar 'n merkbare korrelasie bestaan tussen die KMPM se aangeduide Verlangde opbrengs en die werklike opbrengs oor agt jaar. Die

Tabel 1 Statistiese gegewens met betrekking tot VPI en industriele indekse

\begin{tabular}{lcc}
\hline & $\begin{array}{c}\text { Indeks wat die VPI } \\
\text { volg plus in op- } \\
\text { brengs van 1/2\% per delde opbrengs - ge- } \\
\text { kwartaal lewer } \\
\text { baseer op agt jaar } \\
\text { data per Financial }\end{array}$ & $\begin{array}{c}\text { Industriële indeks } \\
\text { plus beraamde gemid- }\end{array}$ \\
& & Mail \\
\hline $\begin{array}{l}\text { Standaardafwyking (op } \\
\text { opbrengspersentasic) } \\
\text { Korrelasie met industriële }\end{array}$ & 1,16 & 12,44 \\
indeks & & 1,00 \\
Opbrengs (per jaar) & 0,34 & $28,00 \%$ \\
Markbeta (industricel) & $15,12 \%$ & 1,00 \\
KMPM verwagte opbrengs & 0,03 & $28,00 \%$ \\
\hline
\end{tabular}


Tabel 2 Opbrengsstatistieke ten opsigte van aandele en indekse

\begin{tabular}{|c|c|c|c|}
\hline Amdeel of indeks & $\begin{array}{l}\text { Gemiddelde } \\
\text { kwartaallikse } \\
\text { opbrengs \% }\end{array}$ & $\begin{array}{c}\text { Standaard. } \\
\text { afwyking van } \\
\text { opbrengs \% }\end{array}$ & $\begin{array}{l}\text { Koeffisižnt } \\
\text { van variasie }\end{array}$ \\
\hline 1 & 8,30 & 15,06 & 1,81 \\
\hline 2 & 12,66 & 20,28 & 1,60 \\
\hline 3 & 9,27 & 24,11 & 2,60 \\
\hline 4 & 5,33 & 15,8 & 2,98 \\
\hline 5 & 7,51 & 20,21 & 2,69 \\
\hline 6 & 4,19 & 20,99 & 5,02 \\
\hline 7 & 7,68 & 14,62 & 1,90 \\
\hline 8 & 5,93 & 36,23 & 6,11 \\
\hline 9 & 9,88 & 16,31 & 1,65 \\
\hline 10 & 0,80 & 21,39 & 26,88 \\
\hline 11 & 11,53 & 26,30 & 2,30 \\
\hline 12 & 5,51 & 18,75 & 3,40 \\
\hline 13 & 8,72 & 27,84 & 3,19 \\
\hline 14 & 8,10 & 21,45 & 2,65 \\
\hline 15 & 10,83 & 15,60 & 1,44 \\
\hline 16 & 3,29 & 16,87 & 5.13 \\
\hline 17 & 6.27 & 19,21 & 3,07 \\
\hline 18 & 9,58 & 18,38 & 2,14 \\
\hline 19 & 13,21 & 43,53 & 3,30 \\
\hline 20 & 3,98 & 43,07 & 10,82 \\
\hline 21 & 13,73 & 19,34 & 1,41 \\
\hline 22 & 10,53 & 59,56 & 5,66 \\
\hline \multicolumn{4}{|l|}{ Verbruikersprysindeks } \\
\hline plus $1 / 2 \%$ per kwartaal & 3,78 & 1,16 & 0,31 \\
\hline Industriële indeks & 7,00 & 12,44 & 1,78 \\
\hline Goudindeks & 5,62 & 15,60 & 2,78 \\
\hline
\end{tabular}

ex post-opbrengste word dus redelik goed verklaar deur die KMPM.

Benewens dié berekeninge is ' $n$ vergelyking ook uitgevoer tussen die potensielle premie wat behaal kan word in terme van die KMPM, per aandeel, en die werklike beweging in die markpryse van die indiwiduele aandele. Daar is gevind dat die elf aandele met die hoër potensiaal gemiddeld vyf persent beter gevaar het as die elf aandele met die laer potensiaal. Die korrelasiekouffisięnt tussen die potensiële premie en werklike prysbewegings is ook bereken. Die korrelasie het 'n lae maar beduidende 0,36 beloop wat minstens dui op 'n matige kortermyn-ex antevoorspellingskrag. Die gegewens verwys na die kwartal wat op die agtjaarperiode volg.

\section{Portefeuljebestuur en die kapitaalmarkprysmodel}

Volgens die KMPM is daar drie determinante by die bepaling van 'n aandeel se prys, naamlik die opbrengs van die aandeel, die stabiliteit van die opbrengs en die korrelasie van die opbrengs met die van die mark.

Indien die opbrengs van ' $n$ aandeel of portefeulje sou stabiliseer, soos weerspiesl volgens sy standaardafwyking. is die uitgangspunt dat dit interpreteer sal word as 'n laer risiko vir die aandeel of portefeulje. Dit sal lei tor 'n opwaartse herwaardasie van die aandeel of aandele van 'n beleggermaatskappy ten opsigte van sy portefeulje.
Tabel 3 Betas, verlangde opbrengste volgens die KMPM, werklike opbrengste en die persentasie premie op opbrengste haalbaar

\begin{tabular}{|c|c|c|c|c|}
\hline Mautskappy & Beta & $\begin{array}{l}\text { Verlangde } \\
\text { opbreng: }\end{array}$ & $\begin{array}{c}\text { Opbrengs } \\
\text { behaal }\end{array}$ & $\begin{array}{l}\text { Pocensiēle premie } \\
\text { op verlangde op- } \\
\text { brengs haalbaar }\end{array}$ \\
\hline 1 & 0,87 & $26,31 \%$ & $33,20 \%$ & $26 \%$ \\
\hline 2 & 1,26 & $31,38 \%$ & $50,64 \%$ & $61 \%$ \\
\hline 3 & 1,51 & $34,63 \%$ & $37,08 \%$ & $7 \%$ \\
\hline 4 & 0,50 & $21,50 \%$ & $21,32 \%$ & (1)\% \\
\hline 5 & 0,99 & $27,87 \%$ & $30,04 \%$ & $8 \%$ \\
\hline 6 & 1,11 & $29,43 \%$ & $16,76 \%$ & (44)\% \\
\hline 7 & 0,40 & $20,20 \%$ & $30,72 \%$ & $52 \%$ \\
\hline 8 & 1,19 & $30,47 \%$ & $23,72 \%$ & $(22) \%$ \\
\hline 9 & 0,90 & $26,70 \%$ & $39,52 \%$ & $48 \%$ \\
\hline 10 & 0,70 & $24,10 \%$ & $* 03,20 \%$ & $(87) \%$ \\
\hline 11 & 1,33 & $32,29 \%$ & $46,12 \%$ & $43 \%$ \\
\hline 12 & 0,72 & $24,36 \%$ & $22,04 \%$ & (10)\% \\
\hline 13 & 1,39 & $33,07 \%$ & $34,88 \%$ & $5 \%$ \\
\hline 14 & 0,79 & $25,27 \%$ & $32,40 \%$ & $28 \%$ \\
\hline 15 & 0,68 & $23,84 \%$ & $43,32 \%$ & $81 \%$ \\
\hline 16 & 0,11 & $16.43 \%$ & $* 13,16 \%$ & (20)\% \\
\hline 17 & 0,73 & $24,49 \%$ & $25,08 \%$ & $2 \%$ \\
\hline 18 & 0,61 & $22,93 \%$ & $38,32 \%$ & $67 \%$ \\
\hline 19 & 1,19 & $30,47 \%$ & $52,84 \%$ & $73 \%$ \\
\hline 20 & 1,38 & $32,94 \%$ & $15,92 \%$ & (52)\% \\
\hline 21 & 1,08 & $29,04 \%$ & $54,92 \%$ & $89 \%$ \\
\hline 22 & 1,68 & $36,84 \%$ & $42,12 \%$ & $14 \%$ \\
\hline \multicolumn{5}{|l|}{$\mathrm{VPI}+1 / 2 \%$} \\
\hline per kwartaal' & 0,03 & $15,39 \%$ & $15,12 \%$ & $\pm 0 \%$ \\
\hline
\end{tabular}

Dié feit is veral van belang by portefeuljebestuur waar by wyse van samevoeging van 'n aantal aandele die sogenaamde onsistematiese risiko wat eie is aan die aandeel self, minstens gedeeltelik, weggediversifiseer kan word.

Hierdeur word die risiko van die portefeulje verlaag benede die gemiddelde risiko van die samestellende aandele in die portefeulje. Dit word vergestalt in die verlaging van die standaardafwyking van die opbrengs. Hierin is die sinergie van 'n portefeulje gelee. Eie risiko's wat weggediversifiseer kan word sluit onder andere kostestrukture, hefboom- en bestuursrisiko's in.

Dit volg dus dat by die samestelling van 'n ponefeulje ander andere gepoog moet word om die standaardafwyking van die som van die opbrengste per periode van die aandele in die portefeulje te minimaliseer.

Ter illustrasie is die standaardafwykings van die opbrengste van vyf portefeuljes in Tabel 4 bereken en vergelyk met die gemiddelde afwyking van die samestellende andele.

Die daling in standaardafwyking oor die algemeen wys duidelik. Dit blyk ook dat hoe hot die gemiddelde standaardafwyking hoe hot die potensizle persentasieafname. Vergelyk in die verband portefeuljes $A$ en $C$ met $B$ en $D$. Pontefeulje $E$ is in ' $n$ ander opsig eiesoortig en sal later wegelig word.

Indien die markbeta van die portefeulje bereken word op die basis van die markpryse en diwidende van die 
Tabel 4 Standaardafwykings en portefeuljesinergie

\begin{tabular}{lccc}
\hline $\begin{array}{l}\text { Matskappynommers } \\
\text { van aandele in } \\
\text { portefeulje }\end{array}$ & $\begin{array}{c}\text { Gemiddelde } \\
\text { standaard- } \\
\text { afwyking }\end{array}$ & $\begin{array}{c}\text { Portefeulje } \\
\text { standaard- } \\
\text { afwyking }\end{array}$ & $\begin{array}{c}\text { Persentasie } \\
\text { afname }\end{array}$ \\
\hline A) $16,13,19,20$ & 32,83 & 20,51 & $37 \%$ \\
B) $3,11,21,2$ & 22,51 & 18,66 & $17 \%$ \\
C) $13,5,19,20$ & 33,66 & 22,06 & $34 \%$ \\
D) $1,2,9,3$ & 18,94 & 16,35 & $14 \%$ \\
E) 5,16 & 18,54 & 10,69 & $42 \%$ \\
\hline
\end{tabular}

Tabel 5 Gemiddelde beta en portefeulje beta

\begin{tabular}{lccccc}
\hline & Onderakeie & $\begin{array}{c}\text { Gemid- } \\
\text { delde } \\
\text { betre- } \\
\text { feulje }\end{array}$ & $\begin{array}{c}\text { Standaard- } \\
\text { afwyking } \\
\text { van porte- } \\
\text { feulje }\end{array}$ & $\begin{array}{c}\text { Korrelasie } \\
\text { van porte- } \\
\text { feulje } \\
\text { met mark }\end{array}$ & $\begin{array}{c}\text { Porte- } \\
\text { feulje } \\
\text { beta }\end{array}$ \\
\hline A) $0,11,1,39,1,19,1,38$ & 1,02 & 20,51 & 0,61 & 1,01 \\
B) $1,51,1,33,1,08,1,26$ & 1,29 & 18,66 & 0,87 & 1,30 \\
C) $1,39,0,99,1,19,1,38$ & 1,24 & 22,06 & 0,70 & 1,24 \\
D) $0,87,1,26,0,90,1,51$ & 1,13 & 16,35 & 0,87 & 1,14 \\
E) $0,99,0,11$ & 0,55 & 10,69 & 0,64 & 0,55 \\
\hline
\end{tabular}

Tabel 6 Interkorrelasie en portefeuljesinergie

\begin{tabular}{ccc}
\hline Portefeulje & $\begin{array}{c}\text { Gemiddelde } \\
\text { interkorrelasie }\end{array}$ & $\begin{array}{c}\text { Persentasie verbetering } \\
\text { in stabiliteit }\end{array}$ \\
\hline A & 0,15 & $37 \%$ \\
B & 0,58 & $17 \%$ \\
C & 0,26 & $34 \%$ \\
D & 0,65 & $14 \%$ \\
E & -.35 & $42 \%$ \\
\hline
\end{tabular}

onderliggende aandele sal dit aksiomaties gelyk wees aan die gemiddelde beta van die onderskeie aandele. Hieruit kan die sinergie nie blyk nie.
Die voorbeelde in Tabel 5 illustreer dié punt.

Die laer gekombineerde standaardafwyking van die gesamentlike opbrengs sal waarskynlik met inagneming van uitgawes van die belegger self, lei tot 'n markbeoordeling van die belegger op ' $n$ laer beta as die gemiddelde beta van die onderskeie aandele in die portefeulje. Die proses sal by die bespreking van die kapitaalmarklyn verder aandag geniet.

Ter samevatting kan gesê word dat ten einde die portefeulje se standaardafwyking te verminder in vergelyking met die gemiddeld van die onderskeie aandele, dit oor die algemeen lonend sal wees om aandele met hour standaardafwykings eerder as lae standaardafwykings te kombineer.

\section{Interkorrelasle van opbrengste van aandele}

Nog 'n veranderlike wat die graad van verbetering in stabiliteit van die opbrengs van 'n portefeulje in vergelyking met die gemiddeld van die indiwiduele aandele in die portefeulje beïnvloed, is die onderlinge korrelasie tussen die opbrengste van aandele per periode.

Indien daar ' $n$ positiewe korrelasie bestaan, sal daar geen afname in die totale fluktuasies wees vergeleke met die som van die indiwiduele aandele nie. Hoe laer die korrelasie, hoe groter die verbetering.

In Tabel 6 word die gemiddelde korrelasies van die portefeuljes getoon, soos tevore genoem en hul respektiewelike groter stabiliteit by opname in portefeuljes. Let veral op die groot verbetering van portefeulje E nieteenstaande die relatief lae gemiddelde standaardaf wyking.

By die samestelling van ' $n$ effektiewe portefeulje kan 'n matriks van interkorrelasie van aandele van onskatbare waarde wees. 'n Lae gemiddelde korrelasie van 'n aandeel kan hom aantreklik maak vir opname. Tabel 7 dien as voorbeeld daarvan.

Ter verfyning van die portefeulje kan deur middel van trosanalise 'n soortgelyke tabel opgestel word waarin groepe aandele sover moontlik bymekaar of wegliggend ge-

\begin{tabular}{|c|c|c|c|c|c|c|c|c|c|c|c|c|c|c|c|c|c|c|c|c|c|c|}
\hline & I & 2 & 3 & 4 & 5 & 6 & 7 & 8 & 9 & 10 & 11 & 12 & 13 & 14 & 15 & 16 & 17 & $18^{\prime}$ & 19 & 20 & 21 & 22 \\
\hline $\begin{array}{l}1 \\
2 \\
3 \\
4 \\
5 \\
6 \\
7 \\
8 \\
9 \\
10 \\
11 \\
12 \\
13 \\
14 \\
15 \\
16 \\
17 \\
18 \\
19 \\
20 \\
21 \\
22\end{array}$ & $\begin{array}{l}0,60 \\
0,54 \\
0,38 \\
0,30 \\
0,61 \\
0,32 \\
0,11 \\
0,70 \\
0,32 \\
0,43 \\
0,37 \\
0,30 \\
0,29 \\
0,31 \\
0,04 \\
0,46 \\
0,19 \\
0,34 \\
0,14 \\
0,56 \\
0,36\end{array}$ & $\begin{array}{l}0,70 \\
0,42 \\
0,57 \\
0,50 \\
0,30 \\
0,18 \\
0,65 \\
0,33 \\
0,43 \\
0,44 \\
0,64 \\
0,42 \\
0,45 \\
0,19 \\
0,29 \\
0,43 \\
0,27 \\
0,21 \\
0,58 \\
0,26\end{array}$ & $\begin{array}{l}0,26 \\
0,74 \\
0,31 \\
0,40 \\
0,44 \\
0,74 \\
0,28 \\
0,38 \\
0,19 \\
0,59 \\
0,41 \\
0,37 \\
0,02 \\
0,43 \\
0,35 \\
0,21 \\
0,25 \\
0,64 \\
0,22\end{array}$ & $\begin{array}{r}0,33 \\
0,19 \\
0,44 \\
0,15 \\
0,46 \\
0,13 \\
0,16 \\
0,51 \\
0,43 \\
0,16 \\
-0,03 \\
-0,23 \\
0,07 \\
0,31 \\
-0,08 \\
0,10 \\
0,54 \\
0,15\end{array}$ & $\begin{array}{r}0,53 \\
0,28 \\
0,27 \\
0,44 \\
0,14 \\
0,54 \\
0,21 \\
0,62 \\
0,48 \\
0,26 \\
-0,35 \\
0,37 \\
0,17 \\
0,09 \\
0,37 \\
0,52 \\
0,45\end{array}$ & $\begin{array}{l}0,45 \\
0,43 \\
0,47 \\
0,34 \\
0,69 \\
0,09 \\
0,57 \\
0,44 \\
0,24 \\
0,12 \\
0,50 \\
0,17 \\
0,52 \\
0,29 \\
0,61 \\
0,32\end{array}$ & $\begin{array}{r}0,18 \\
0,47 \\
0,09 \\
0,11 \\
0,36 \\
0,37 \\
0,29 \\
-0,00 \\
0.12 \\
0,28 \\
0,03 \\
0,32 \\
0,18 \\
0.39 \\
0,06\end{array}$ & $\begin{array}{l}0,19 \\
0,06 \\
0,71 \\
0,04 \\
0,26 \\
0,18 \\
0,16 \\
0,44 \\
0,36 \\
0.37 \\
0,38 \\
0,03 \\
0,47 \\
0,02\end{array}$ & $\begin{array}{r}0,70 \\
0,65 \\
0,74 \\
0,46 \\
0,44 \\
0,47 \\
0,47 \\
0,18 \\
\\
0,23 \\
0,36 \\
0,35 \\
0,54 \\
0,26 \\
0,35 \\
-0,03 \\
0,25 \\
0,25 \\
0,05 \\
0,16 \\
0,62 \\
0,19\end{array}$ & $\begin{array}{c}0,32 \\
0,33 \\
0,28 \\
0,13 \\
0,14 \\
0,34 \\
0,09 \\
0,06 \\
0,23 \\
\\
0,18 \\
0,06 \\
0,43 \\
0,25 \\
-0,12 \\
0,02 \\
0,18 \\
0,25 \\
0,23 \\
0,43 \\
0,36 \\
0,13\end{array}$ & $\begin{array}{l}0,43 \\
0,43 \\
0,58 \\
0,16 \\
0,54 \\
0,69 \\
0,11 \\
0,70 \\
0,36 \\
0,18 \\
0,14 \\
0,50 \\
0.40 \\
0,26 \\
0,34 \\
0,49 \\
0,31 \\
0,56 \\
0,07 \\
0,56 \\
0,45\end{array}$ & $\begin{array}{r}0,37 \\
0,44 \\
0,19 \\
0,51 \\
0,21 \\
0,09 \\
0,36 \\
0,05 \\
0,35 \\
0,06 \\
0,14 \\
0,35 \\
0,09 \\
0,39 \\
-0,12 \\
0,17 \\
0,30 \\
0,18 \\
-0,14 \\
0,23 \\
0,22\end{array}$ & $\begin{array}{l}0,30 \\
0,64 \\
0,60 \\
0,43 \\
0,62 \\
0,57 \\
0,37 \\
0,26 \\
0,54 \\
0,42 \\
0,50 \\
0,35 \\
0,44 \\
0,14 \\
0,01 \\
0,28 \\
0,29 \\
0,17 \\
0,33 \\
0,51 \\
0,40\end{array}$ & $\begin{array}{l}0,30 \\
0,42 \\
0,41 \\
0,16 \\
0,48 \\
0,44 \\
0,29 \\
0.18 \\
0,26 \\
0,25 \\
0,40 \\
0,09 \\
0,44 \\
0,11 \\
0,08 \\
0,52 \\
0,10 \\
0,33 \\
0.33 \\
0,55 \\
0,35\end{array}$ & $\begin{array}{r}0,30 \\
0,45 \\
0,37 \\
-0,03 \\
0,26 \\
0,24 \\
-0,00 \\
0,16 \\
0,35 \\
-0,12 \\
0,26 \\
0,39 \\
0,14 \\
0,11 \\
-0,04 \\
0,18 \\
0,38 \\
0,10 \\
-0,03 \\
0,36 \\
-0,12\end{array}$ & $\begin{array}{r}0,03 \\
0,02 \\
0,01 \\
-0,23 \\
-0,35 \\
0,12 \\
0,12 \\
0,44 \\
-0,03 \\
0,20 \\
0,34 \\
-0,12 \\
0,01 \\
0,08 \\
-0,04 \\
0,06 \\
-0,03 \\
0,47 \\
-0,08 \\
0,11 \\
-0,11\end{array}$ & $\begin{array}{l}0,46 \\
0,30 \\
0,43 \\
0,07 \\
0,37 \\
0,50 \\
0,28 \\
0,36 \\
0,25 \\
0,18 \\
0,49 \\
0,17 \\
0,28 \\
0,52 \\
0,18 \\
0,06 \\
0,14 \\
0,52 \\
0,19 \\
0,37 \\
0,37\end{array}$ & $\begin{array}{r}0,18 \\
0,43 \\
0,35 \\
0,30 \\
0,17 \\
0,17 \\
0,26 \\
0,37 \\
0,25 \\
0,26 \\
0,31 \\
0,30 \\
0,29 \\
0,10 \\
0,38 \\
-0,02 \\
0,14 \\
0,05 \\
0,02 \\
0,26 \\
-0,06\end{array}$ & $\begin{array}{l}0.34 \\
0.27 \\
0.21 \\
-0,08 \\
0,09 \\
0.52 \\
0.32 \\
0.38 \\
0.05 \\
0.23 \\
0.56 \\
0.18 \\
0.17 \\
0.33 \\
0.10 \\
0.47 \\
0.52 \\
0,05 \\
0.04 \\
0.17 \\
0.30\end{array}$ & 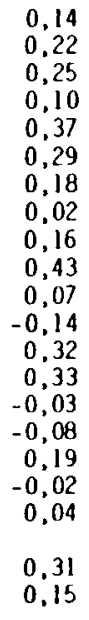 & $\begin{array}{l}0.56 \\
0.57 \\
0.64 \\
0.54 \\
0.52 \\
0.61 \\
0.39 \\
0.47 \\
0.62 \\
0.36 \\
0.56 \\
0.23 \\
0.51 \\
0.56 \\
0.36 \\
0.11 \\
0.37 \\
0.26 \\
0.17 \\
0.31 \\
0.02\end{array}$ & $\begin{array}{r}0,36 \\
0,26 \\
0,22 \\
0,15 \\
0,45 \\
0,32 \\
0,06 \\
0.02 \\
0,19 \\
0,13 \\
0.45 \\
0,22 \\
0,39 \\
0,35 \\
-0,12 \\
-0,11 \\
0,37 \\
-0,06 \\
0,30 \\
0,15 \\
0,02\end{array}$ \\
\hline & 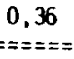 &, 41 & 0,43 & $=$ & 0,3 & & & & & & & & & & & & & & & & & \\
\hline
\end{tabular}

Tabel 7 Matriks van korrelasie tussen aandele 
rangskik word aan die hand van hulle onderlinge verwantskap.

So 'n matriks is 'n nuttige hulpmiddel by die keuse van aandele vir 'n portefeulje met die oog op maksimalisering van die verbetering in die stabiliteit van opbrengste by die samestelling van 'n portefeulje.

\section{Die beoordeling van die effekthitelt van die samestelling van 'n portefeulje}

Die beoordeling van die kwaliteit van 'n portefeulje se samestelling geskied aan die hand van die kapitaalmarklyn wat as volg beskryf word:

$$
\begin{aligned}
y= & R_{f}+b x, \text { waar } \\
y= & \text { die opbrengs vereis van die portefeulje } \\
R_{f}= & \text { 'n risikovrye opbrengs } \\
x \quad= & \text { die standaardafwyking van die opbrengs van } \\
& \text { die portefeulje } \\
b \quad= & \text { die regressiekoéffisięnt van die standaard- } \\
& \text { afwyking }
\end{aligned}
$$

Aan die hand van die benadering gevolg en kapitaalmarkinligting soos reeds verskaf, kan die lyn as volg daar uitsien:

\section{Berekening van $b$}

Waar $X^{1}=12,44$

Waar $\mathrm{X}^{2}=1,16$

$$
\mathbf{y}^{1}=28,00 \% \text { (industriele indeks) }
$$

indeks)

Dit wil sê:

$$
\begin{aligned}
\text { b } & =\frac{(28,00-15,39)}{(12,44-1,16)} \\
& =1,12
\end{aligned}
$$

Dit wil sê: verwagte opbrengs $y=16,50+1,12 x$

Indien die werklike opbrengs van die portefeulje bo die lyn val, is die portefeulje effektief en indien dit onder die lyn val, is dit oneffektief.

By die trek van die markpryslyn, of -kromme, kan natuurlik van verdere puntdata gebruik gemaak word, byvoorbeeld ten opsigte van risikovrye beleggings.

Deels weens die geweldige hoë inflasiekoers wat reeds vir meer as 'n dekade in Suid-Afrika ondervind word, sal gevind word dat verwagte opbrengste volgens die kapitaalmarklyn en die koste van ekwiteit volgens die KMPM beduidend mag verskil. ' $n$ Verdere rede is dat by die toepassing van die KMPM die industrięle indeks veral gebruik word as verteenwoordigend van die mark terwyl dit inderwaarheid slegs 'n gedeelte van die mark verteenwoordig. Soortgelyke verteenwoordigingsprobleme word ook ondervind by die berekening van die kapitaalmarklyn.

Ons stel voor dat die tegnieke saam aangewend moet word by portefeuljebestuur.

Dit mag ook van nut wees om by die toepassing van die KMPM en die kapitaalmarklyntegniek alternatiewe berekeninge te doen op die basis van opbrengste wat aangepas is deur die verbruikersprysindeks of groothandelsprysindeks as deflator te gebruik. Op dié wyse sal standaardafwykings van opbrengste, markbetas, ensovoorts, waarskynlik as suiwerder beskou kan word.

\section{BeperkInge van die kapitaalmarkprysmodel en dle praktiese nut daarvan}

Die KMPM model het die volgende gebreke wat betref sy onderliggende aannames:

- Die aanname van reglynige opbrengste is bloot 'n benadering en lewer in uiterste omstandighede onbetroubare resultate.

- Die doeltreffende markhipotese is hoogstens deels geldig.

- Finansiële data se voorspellingskrag is aan beperkinge onderhewig.

- Die strukturele stabiliteit van die mark is slegs op kort termyn geldig en eenmalige wesentlike gebeure kan selfs censklaps 'n verandering veroorsaak.

- Die opbreekwaardes van maatskappye is waarskynlik van groter belang as wat deur die KMPM weergegee word, veral waar ontoereikende winste gemaak word.

- Die nie-sistematiese risiko's van maatskappye word as deurlopend aanvaar alhoewel dit wesenlik kan verander.

- Die corwegende posisie wat die gemiddelde markopbrengs neem in die KMPM lei waarskynlik tot onvolledigheid van faktore wat in berekening gebring word.

Die belangrike plek wat stabiliteit van opbrengs inneem in die KMPM en die onteenseglike belangrikheid van dié faktor leen egter groot gewig aan die model.

\section{Gevolgtrekking}

Portefeuljebestuur kan baat by tegnieke en hulpmiddele soos hierin uiteengesit. Daar moet egter kennis geneem word van die beperkinge en aannames waarop die tegnieke gegrond is, aangesien veral die inflasietoestand wat nou reeds so lank voortduur emstige verwringinge in die mark kan veroorsaak en die andersins redelike aannames onder verdenking plaas.

\section{Nota}

1. Soos onder andere aangewend en beskryf in 'The measurement of risk' deur J. le R. Retief, W.D. Hamman, J.F. Affleck-Graves, gepubliseer in 'SuidAfrikaanse Tydskrif vir Bedryfsleiding' , 1984, (15) 4.

\section{Verwysings}

B.B.P. Publishing Limited 1989. CIMA Study Text Stage 4, Management Accounting, Financial Management.

Bradfield D.J. 1989. A review of capital market theory from a South African perspective. De Ratione, Volume 3, Number 1, 2-7.

Bradfield D.J. 1989. A note on the estimation problems caused by thin-trading on the Johannesburg Stock Exchange. De Ratione, Volume 3, Number 1, 22-25.

Maher M.G.K., Spiers D.S., 1990. The Stock Exchange Handbook (vir die Johannesburgse Effektebeurs). Johannesburg: Flesch Financial Publications (Pty.) Ltd.

Retief J. le R., Harmman W.D., Affleck-Graves J.F. 1984. The Measurement of Risk. S.A. Tydskr. Bedryfsl., Volume 15, Nommer 4, 205-211. 
Retief J. le R., Hamman W.D., Affleck-Graves J.F. 1984. Leverage $=$ Risk? Empirical findings for the Johannesburg Stock Exchange. The Investment Analysts Journal, November, 23-29.

Times Media Limited, Financial Mail, 1982-1990.

\section{Bylae}

Die voorbeelde

Maatskappynaam

Suncrush

Sentrachem

Irvin \& Johnson

Grinaker Holdings

Gypsum Industries

Anglo-Vaal Industries

Murray \& Roberts Holdings

Chemikaliex
Gubb \& Inggs

Towles Edgar Jacobs

Abercom Groep

Berzack Brothers (Holdings)

Claude Neon Lights SA

McCarthy Groep

Brian Porter Holdings

Consol

Press Supplies Holdings

General Optical Company

Drank en hotelle

Voedsel

Bounywerheid

Bounywerheid

Industriěle houers

Bounywerheid

Africa

Mathieson \& Ashley
Klerasie

Klerasie

Ingenieurswese

Ingenieurswese

Ingenieurswese

Motors

Motors

Papier en verpakking

Papier en verpakking

Farmaseuties en

medies

The Union Cold Storage of South

Farmaseuties en

medies

Drukkery

Winkels

Vervoer

Vervoer 